論文

\title{
落葉広葉樹-アカマツ混交林およびスギ人工林における落葉に 伴う放射性セシウムの移行
}

\author{
久留景吾*,1,4 恩田裕 ${ }^{2} \cdot$ 河 守 歩 $^{3} \cdot$ 加藤弘 亮 $^{2}$
}

\begin{abstract}
福島第一原子力発電所の事故により放射性物質が降下した福島県内の林相の異なる森林 3 地点を対象に, 樹冠から林床へ降 下するリターを通じた放射性セシウムの移行の特徵を明らかにした。事故後 4 力月目から 11 力月間, 定期的にリターの ${ }^{134} \mathrm{Cs}$ および ${ }^{137} \mathrm{Cs}$ の放射能濃度を測定し, 降下量の解析を行った。リターの放射能濃度は総じて落葉広葉樹一アカマツ混交林よりも スギ人工林で高い值を示したのは, 事故発生時に広葉樹が落葉していたために, 飛散した放射性セシウムの多くが広葉樹の樹 冠を通過して林床へ降下した結果と考えられる。一方，スギ人工林ではリターに伴う放射性セシウム降下量の累積值が大きく 上昇し続けており, 調査終了時でも樹冠に放射性セシウムが相当量残存していることが確認された。2011年 10 月以降各林分で のリターの放射能濃度が概ね横ばいに推移する中, 放射性セシウム降下量は樹冠からのリター降下量に大きく影響されている ことが明らかとなった。今後は降下するリターに加え, 樹冠における生葉の鉛直分布や林床でのリ夕ーの平面分布, 林内雨や 樹幹流などを含めて総合的に放射性セシウムの移行機構を解明していく必要がある。 キーワード：リター, 放射性セシウム, 移行, 降下量, 福島第一原子力発電所事故
\end{abstract}

\begin{abstract}
Keigo Hisadome, ${ }^{*, 1,4}$ Yuichi Onda, ${ }^{2}$ Ayumi Kawamori, ${ }^{3}$ Hiroaki Kato ${ }^{2}$ (2013) Migration of Radiocaesium with Litterfall in Hardwood-Japanese Red Pine Mixed Forest and Sugi Plantation. J Jpn For Soc 95: 267-274 To clarify radiocaesium migration with litterfall from the tree canopy to the forest floor, a study was conducted in the three different forests in Fukushima Prefecture where radionuclides released from the Fukushima Daiichi Nuclear Power Plant (FDNPP) were deposited. Concentrations of ${ }^{134} \mathrm{Cs}$ and ${ }^{137} \mathrm{Cs}$ in the litterfall had been periodically monitored for 11 months since four months after the accident and were analyzed. The concentrations in the litter samples were generally higher in the cedar forests than those in the hardwood-Japanese red pine mixed forest; because the hardwood trees had no leaves at the time of the accident, most of the resuspended radiocaesium is considered to have been deposited on the forest floor through canopies. Meanwhile, the cumulative deposition of radiocaesium in the cedar forests was found to be higher than that in the hardwood-Japanese red pine mixed forest. This confirmed that large amount of radiocaesium still remains in the tree canopies. Although not many differences were observed in the radiocaesium concentrations in the litterfall since October 2011 in any forest stand, radiocaesium deposition remarkably increased due to a large amount of litterfall from the canopies. Together with the litterfall, vertical distribution of fresh leaves in the canopies, horizontal distribution of litter on the forest floor, throughfall, and stemflow should be monitored to clarify the comprehensive migration of radiocaesium in the future.

Key words: litter, radiocaesium, migration, deposition, Fukushima Dai-ichi Nuclear Power Plant accident
\end{abstract}

\section{I. は じめ に}

2011 年 3 月に発生した東京電力株式会社福島第一原子 力発電所（以下，「福島第一原発」とする）の事故に伴い, 同発電所の原子炉施設から環境中へ大量の放射性物質が放 出された。これらの放射性物質は地表面に降下した後, 河 川等を通じて水や土壤とともに環境中を移行することが確 認されている。文部科学省・農林水産省（2012）や日本原 子力研究開発機構 (2013) では, 事故直後の土壤の表面状 態が変化する前からこれらの放射性物質についての沈着状 況の変化傾向の把握を進めており, その成果はこれらの放 射性物質の人間への影響評価や除染計画の策定等に反映さ れてきているところである。今後, 放射性物質の移行機構
を解明し予測モデルを構築していくためには, 森林・土壌・ 地下水・河川水中等の様々な自然環境を通じて放射性物質 の分布状況とその変化傾向を詳細に確認していくことが必 要である。

福島第一原発事故で放射性物質により污染された土地 の大部分は森林である (Hashimoto et al. 2012)。森林に 降下した放射性物質は, 常緑樹の場合の多くは最初に樹 冠に沈着した後, 樹冠を通過する雨（以下,「林内雨」と する）により洗い落とされたり（Bonnett and Anderson 1993), 雨風によって樹体か葉や小枝がはがされて落下す るなどにより，林床へと移行していく（Bunzl et al. 1989 ； Schimmack et al. 1993 ; Tikhomirov and Shcheglov 1994)。 林床一降下した放射性物質は, 土壤生物により分解されて

*連絡先著者 (Corresponding author) E-mail : kgo.hisadome@ajiko.co.jp

筑波大学生命環境系 † 305-8572 つくば市天王台 1-1-1（Faculty of Life and Environmental Sciences, University of Tsukuba, 1-1-1 Tennodai, Tsukuba 305-8572, Japan)

筑波大学アイソトープ環境動態研究センター 305-8572 つくば市天王台 1-1-1 (Center for Research in Isotopes and Environmental Dynamics, University of Tsukuba, 1-1-1 Tennodai, Tsukuba 305-8572, Japan)

3 筑波大学生命環境科学研究科７ 305-8572 つくば市天王台 1-1-1 (Graduate School of Life and Environmental Sciences, University of Tsukuba, 1-1-1 Tennodai, Tsukuba 305-8572, Japan)

現勤務先：アジア航測株式会社 † 215-0004 川崎市麻生区万福寺 1-2-2 (Asia Air Survey Co., Ltd., 1-2-2 Manpukuji, Asao, Kawasaki 2150004, Japan)

(2013 年 5 月 23 日受付, 2013 年 8 月 20 日受理) 
いない林床の葉や枝・果実・樹皮・倒木など（以下,「リター」 とする）が堆積している層の分解が進むとともに土壤へと 移行する。土䁃に沈着した放射性物質は，降下直後はその 8 割以上が地表面から $2 \mathrm{~cm}$ 以浅にとどまるが (Kato et al. 2012)，時間の経過とともに，土壤から植物へ根からの吸 い上げや（Bunzl et al. 1999）, 表面流出による森林外への 流出（Nylèn and Grip 1997）などの形で再移動していく。 以上より，放射性物質の降下した土地の大部分を占める森 林について，その樹冠や林床に沈着した放射性物質がどの ように移行・変化していくのかを詳細に把握することが重 要である。

そこで，本研究では，福島第一原発から放出された放射 性物質が降下した森林内で，樹冠から降下するリターに着 目し，林相の異なる 3 地点でリターの降下に伴い樹冠から 林床へ移行する放射性物質の分布状況の変化を調查するこ とにより，各林分における放射性物質の移行状況と蓄積状 況の特徵を把握・整理したものである。

\section{II. 調查地と方法}

\section{1. 調査地}

本研究では，その成果が森林環境における放射性物質の 移行・蓄積状況の把握や今後の住民帰還のための基礎資料 とされうることを考慮し, 比較的放射性物質沈着量の高い, 計画的避難区域内である，阿武隈川水系口太川上流地域の 福島県伊達郡川俣町山木屋地区を調査対象地として選定し た（図-1）。山木屋地区は，文部科学省（2011）による第 3 次航空機モニタリング（2011 年 7 月 2 日時点）において, 放射性セシウム $\left({ }^{137} \mathrm{Cs}\right)$ の蓄積量が $300 \sim 600 \mathrm{kBq} / \mathrm{m}^{2}$ と 評価されている地域である。

この山木屋地区内において，異なる林相での放射性物質 の移行・蓄積状況を把握するために，針葉樹林として，ス ギ壮齢林（樹齢 40 50 年）1 地点，およびスギ若齢林（樹 齢 18 年） 1 地点を選定し, 針広混交林として, ナラガシ ワ等とアカマツが生育している混交林（以下，「落葉広葉 樹 -アカマツ混交林」とする）1地点を選定した。

\section{2. 調查方法}

本研究では，それぞれの森林内において樹冠から降下す るリターを採取し，森林内の放射性物質の分布状況と時間 の経過に伴う放射性物質の蓄積状況の変化について調查を 実施した。調查は 2011 年 7 月 3 日に開始し, 2012 年 5 月 25 日までに採取した試料のデー夕をとりまとめ, 結果の 評価を実施した。期間中の試料採取は原則として 2 週間 に 1 度実施した。2011 年 11 月期は落葉量が多かったため 1 週間扮きの試料回収を行った。2012 年 1 2 月は試料量 が少なかったため，試料採取頻度を月 1 回とした。このう ち 2012 年 1 月 24 日の針葉樹林と 2012 年 2 月 7 日の落葉 広葉樹一アカマツ混交林では捕捉されたリター量が少なく, 2012 年 4 月 13 日の落葉広葉樹一アカマツ混交林ではリター が捕捉されなかったことから,試料の回収を行わなかった。

樹冠から林床へ降下するリターを採取するために，スギ

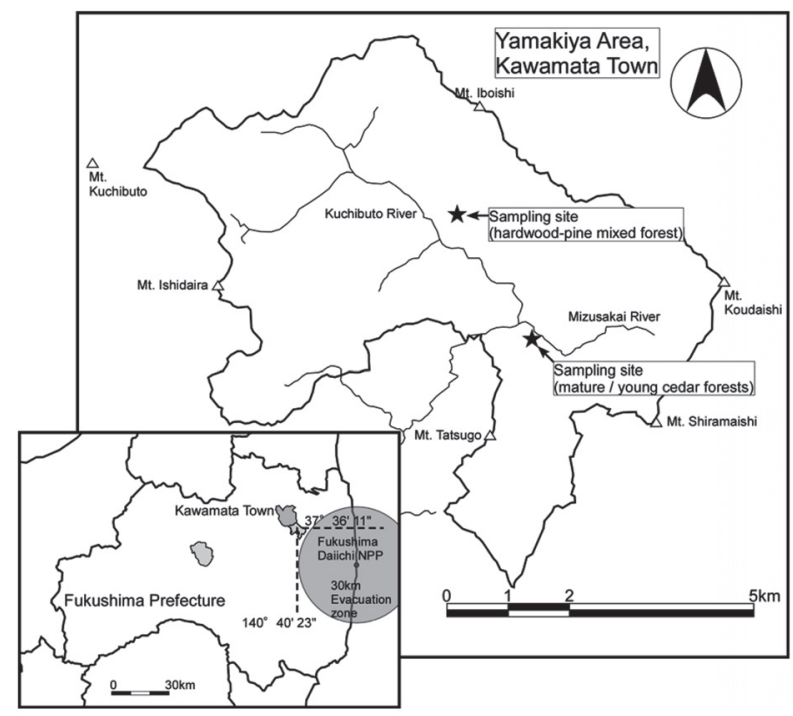

図-1. 調査対象地案内図 Location of the study site.

壮齢林・スギ若齢林・落葉広葉樹一アカマツ混交林に, 図2 (a)～(c) に示すとおりの配置で, それぞれ 3 基のリター トラップを設置した。リタートラップは, 図-2（b）（c）の 写真に示すと抢り, $1 \mathrm{~m} \times 1 \mathrm{~m}$ の枠に目の細かいメッシュを 取り付け，林床に落下するリターを捕捉する構造になって いる。リタートラップに捕捉されたリターの試料は，全量 をポリエチレン製のバッグに封入し，実験室に持ち帰った。

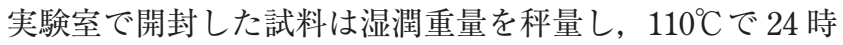
間炉乾燥させた後, 全乾燥重量を秤量し, 粉砕機で粉体に した。粉体を容量 $100 \mathrm{~mL}$ のポリスチレン製ねじ口U 型容 器に分取して放射能濃度測定用の試料とした。当該試料に ついてゲルマニウム半導体検出器を使用し放射能濃度を測 定した。本測定システムは $\mathrm{N}$ 型逆電極高純度ゲルマニウ ム検出器 (EGC25-195-R, Canberra-Eurisys, Meriden, USA), および増幅器 (PSC822, Canberra, Meriden, USA), マルチ チャンネルアナライザ (DSA1000, Canberra, Meriden, USA) から構成される。測定対象とした放射性物質は, 放射性七 シウム $\left({ }^{134} \mathrm{Cs},{ }^{137} \mathrm{Cs}\right)$ とした。室内試料処理および測定にあ たっては試料のコンタミネーションの防止に留意した。測 定の結果得られたスペクトルデータから放射性セシウムの 放射能濃度および放射性セシウム量を解析により求めた。 放射性セシウムの放射能濃度はそれぞれの試料採取日の值 に補正した。

降下してきたりターについて，枝や葉，皮等の部位別の 放射能濃度および放射性セシウム降下量の特徵を明らかに するため, これらの部位別の試料測定を行った。比較的ま とまったリター降下量を得ることができた 2012 年 4 月 13 日から 5 月 25 日までに捕捉された試料を対象に, 実験室 で炉乾燥させたリターを部位別に分けたのち秤量し，それ ぞれについて放射能濃度を測定した。針葉樹林の試料につ いては葉, 枝, 皮, 種子の 4 種類に分別し, 落葉広葉樹- 
(a)

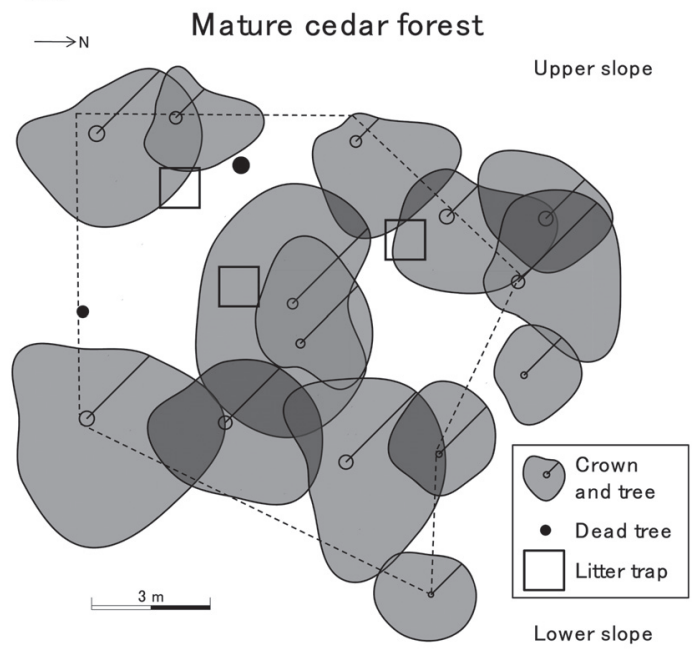

(b)

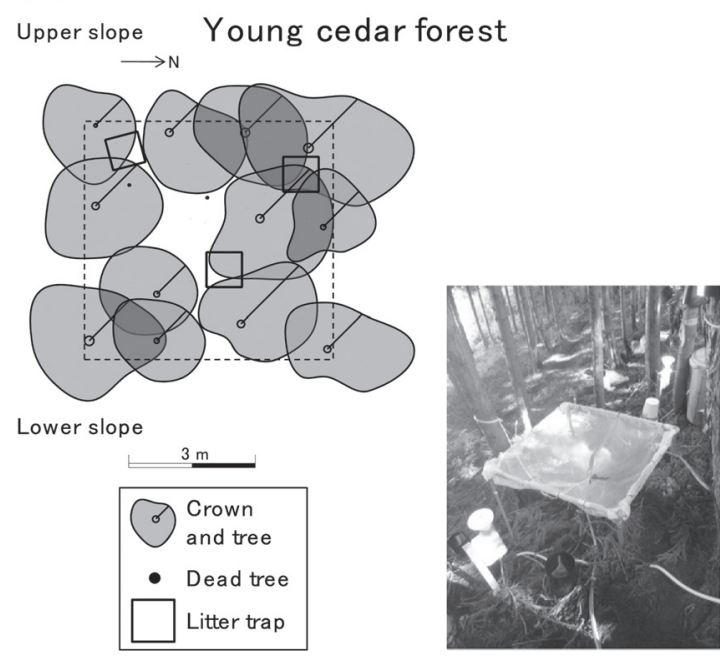

アカマツ混交林の試料については広葉樹の葉，枝，アカマ ツの皮，種子，葉の 5 種類に分別した。

\section{III. 調 查 結 果}

\section{1. 森林内で降下するリターの放射能濃度}

それぞれの森林において，林内の 3 カ所のリタートラッ プで採取したリターについて核種分析を行った。算出され た 3 力所の放射性セシウムの放射能濃度を加重平均した結 果を表-1 および図-3（a)〜（e）に示す。いずれの森林でも 放射性セシウムの放射能濃度は観測期間を通じて検出され ており, ${ }^{134} \mathrm{Cs}$ と ${ }^{137} \mathrm{Cs}$ とではほぼ類似した傾向を示した。 総じて放射能濃度は落葉広葉樹一アカマツ混交林よりも針 葉樹林において值が高くなる傾向が示された。

針葉樹林のスギ壮齢林においては, 7 月 31 日〜 8 19 日に脱落した試料の放射性セシウムの放射能濃度が最も 高い值を示し $\left({ }^{134} \mathrm{Cs}\right.$ で $330.5 \mathrm{kBq} / \mathrm{kg},{ }^{137} \mathrm{Cs}$ で $398.4 \mathrm{kBq} /$ $\mathrm{kg}), 11$ 月 12 日以降は概ね $80 \mathrm{kBq} / \mathrm{kg}$ 以下の值で推移し た（図-3(a)）。スギ若齢林においては，8月 19 日〜9月 23 日に脱落した試料の放射性セシウムの放射能濃度が最 (c)
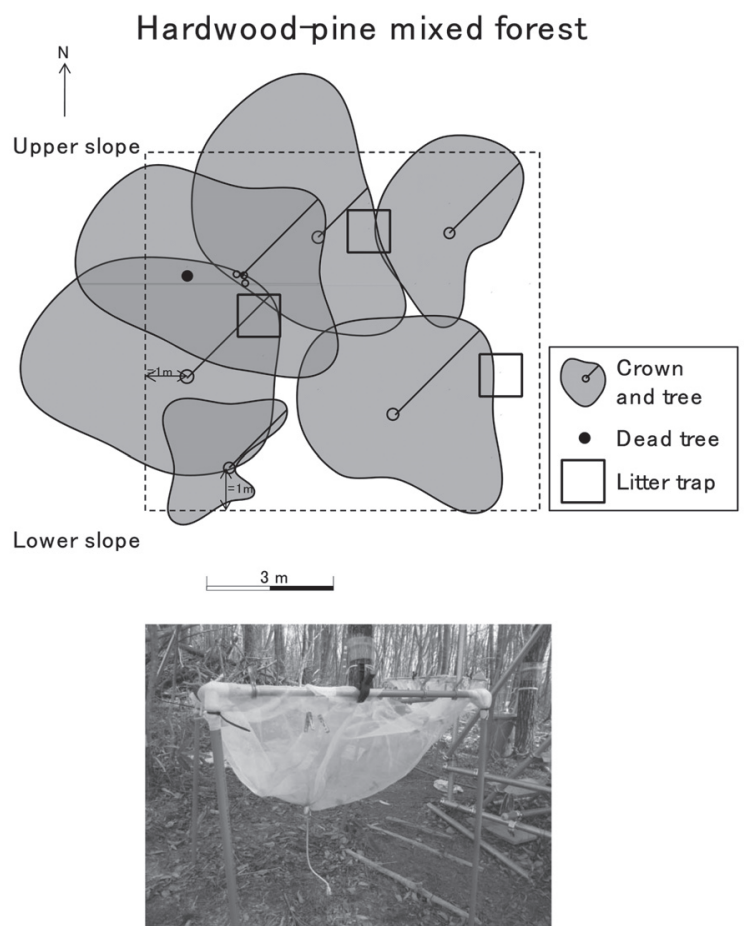

図-2. 調查地に㧍けるプロット配置図掞よびリタートラップ設置 状沉

Arrangement of sampling plot and litter trap images at study site.

(a) Mature cedar forest, (b) Young cedar forest, (c) Hardwood-Japanese red pine mixed forest.

も高かった $\left({ }^{134} \mathrm{Cs}\right.$ で $138.6 \mathrm{kBq} / \mathrm{kg},{ }^{137} \mathrm{Cs}$ で $163.9 \mathrm{kBq} /$ $\mathrm{kg}$ ）ものの， スギ壮齢林と比較して低い值を示した。そ の後は $50 \sim 120 \mathrm{~Bq} / \mathrm{kg}$ 程度の值で推移した（図-3(b))。

落葉広葉樹一アカマツ混交林の試料は, 広葉樹と, アカ マツの葉に分けて測定した。これらを分けて測定した理由 として, 広葉樹は落葉樹であるため福島第一原発事故発生 時には落葉していたが，アカマツは常緑樹であるため同事 故発生当時にも葉が残存していたと考えられることから, それぞれの葉に付着している放射性セシウムの放射能濃度 が異なると考えられるためである。広葉樹試料については, 7 月 31 日〜 8 月 19 日の放射性セシウムの放射能濃度が 高い傾向を示した $\left({ }^{134} \mathrm{Cs}\right.$ で $103.8 \mathrm{kBq} / \mathrm{kg},{ }^{137} \mathrm{Cs}$ で 122.9 $\mathrm{kBq} / \mathrm{kg}$ ，図-3 (c))。アカマツ試料では，8月 19 日〜 12 月 5 日に広葉樹よりも高い值で推移した。 12 月 5 日〜 12 月 28 日,および 1 月 24 日〜 3 月 9 日に脱落した試料からは, ${ }^{134} \mathrm{Cs}$ が検出されなかった（図-3(d))。

また, 表-1より, 各期間におけるリター降下量（総乾 燥重量）を比較した結果，針葉樹林のスギ壮齢林では 9 月 23 日〜 5 月 25 日に他の林分に比べて大量のリター降下が 
表-1. リターの放射性セシウムの放射能濃度測定結果 $\left({ }^{134} \mathrm{Cs}\right.$ 抢よび $\left.{ }^{137} \mathrm{Cs}, 2011 / 7 / 3 \sim 2012 / 5 / 25\right)$

The result of measured radioactivity about litter samples $\left({ }^{134} \mathrm{Cs}\right.$ and ${ }^{137} \mathrm{Cs}$, 2011/7/3 2012/5/25).

\begin{tabular}{|c|c|c|c|c|c|c|c|c|c|c|}
\hline \multirow[b]{4}{*}{ Sampling date } & \multicolumn{10}{|c|}{ Cedar forest } \\
\hline & \multicolumn{5}{|c|}{ (Mature) } & \multicolumn{5}{|c|}{ (Young) } \\
\hline & \multirow{2}{*}{$\begin{array}{c}\text { Dry } \\
\text { weight } \\
\left(\mathrm{g} / \mathrm{m}^{2}\right)\end{array}$} & \multicolumn{2}{|c|}{${ }^{134} \mathrm{Cs}$} & \multicolumn{2}{|c|}{${ }^{137} \mathrm{Cs}$} & \multirow{2}{*}{$\begin{array}{c}\text { Dry } \\
\text { weight } \\
\left(\mathrm{g} / \mathrm{m}^{2}\right)\end{array}$} & \multicolumn{2}{|c|}{${ }^{134} \mathrm{Cs}$} & \multicolumn{2}{|c|}{${ }^{137} \mathrm{Cs}$} \\
\hline & & $\begin{array}{c}\text { Radio- } \\
\text { activity } \\
(\mathrm{kBq} / \mathrm{kg})\end{array}$ & $\begin{array}{l}\text { S.E. } \\
+/-\end{array}$ & $\begin{array}{c}\text { Radio- } \\
\text { activity } \\
(\mathrm{kBq} / \mathrm{kg})\end{array}$ & $\begin{array}{l}\text { S.E. } \\
+/-\end{array}$ & & $\begin{array}{c}\text { Radio- } \\
\text { activity } \\
(\mathrm{kBq} / \mathrm{kg})\end{array}$ & $\begin{array}{l}\text { S.E. } \\
+/-\end{array}$ & $\begin{array}{c}\text { Radio- } \\
\text { activity } \\
(\mathrm{kBq} / \mathrm{kg})\end{array}$ & $\begin{array}{l}\text { S.E. } \\
+/-\end{array}$ \\
\hline $2011 / 7 / 31$ & 6.53 & 98.0 & 4.8 & 114.4 & 5.4 & 4.68 & 94.9 & 5.5 & 101.2 & 5.8 \\
\hline 2011/8/19 & 2.79 & 330.5 & 10.1 & 398.4 & 11.5 & 5.06 & 135.4 & 6.1 & 154.7 & 6.9 \\
\hline $2011 / 9 / 23$ & 10.07 & 253.1 & 7.3 & 295.9 & 7.6 & 4.45 & 138.6 & 5.6 & 163.9 & 5.7 \\
\hline $2011 / 10 / 21$ & 33.83 & 102.4 & 2.9 & 109.6 & 2.7 & 7.50 & 79.5 & 4.8 & 97.2 & 5.0 \\
\hline $2011 / 11 / 5$ & 27.64 & 60.0 & 2.3 & 53.7 & 2.1 & 6.79 & 57.0 & 3.9 & 68.9 & 4.0 \\
\hline 2011/11/12 & 3.91 & 50.0 & 3.3 & 64.2 & 3.6 & 5.17 & 57.2 & 3.5 & 76.7 & 3.9 \\
\hline $2011 / 11 / 19$ & 123.37 & 28.4 & 1.7 & 24.5 & 1.3 & 46.19 & 89.5 & 2.9 & 80.7 & 2.3 \\
\hline $2011 / 12 / 5$ & 152.45 & 42.3 & 2.2 & 35.1 & 1.7 & 58.68 & 95.9 & 3.2 & 81.2 & 2.7 \\
\hline $2011 / 12 / 28$ & 39.31 & 47.9 & 2.3 & 41.2 & 1.8 & 109.83 & 61.7 & 3.0 & 58.2 & 2.5 \\
\hline $2012 / 2 / 7$ & 20.74 & 52.6 & 2.8 & 50.0 & 2.4 & 73.58 & 124.0 & 3.4 & 125.8 & 3.1 \\
\hline $2012 / 3 / 8$ & 38.74 & 77.3 & 2.7 & 73.0 & 2.3 & 20.42 & 67.7 & 2.8 & 61.6 & 2.4 \\
\hline $2012 / 4 / 13$ & 208.26 & 40.6 & 1.8 & 40.8 & 1.7 & 24.15 & 61.0 & 2.3 & 64.4 & 2.1 \\
\hline \multirow[t]{4}{*}{$2012 / 5 / 25$} & 76.11 & 36.9 & 5.8 & 43.3 & 6.8 & 31.12 & 81.6 & 15.0 & 97.6 & 16.5 \\
\hline & \multicolumn{10}{|c|}{ Hardwood-pine mixed forest } \\
\hline & \multicolumn{5}{|c|}{ (Broad leaf) } & \multicolumn{5}{|c|}{ (Pine needle) } \\
\hline & \multirow{2}{*}{$\begin{array}{c}\text { Dry } \\
\text { weight } \\
\left(\mathrm{g} / \mathrm{m}^{2}\right)\end{array}$} & \multicolumn{2}{|c|}{${ }^{134} \mathrm{Cs}$} & \multicolumn{2}{|c|}{${ }^{137} \mathrm{Cs}$} & Dry & \multicolumn{2}{|c|}{${ }^{134} \mathrm{Cs}$} & \multicolumn{2}{|c|}{${ }^{137} \mathrm{Cs}$} \\
\hline Sampling date & & $\begin{array}{c}\text { Radio- } \\
\text { activity } \\
(\mathrm{kBq} / \mathrm{kg})\end{array}$ & $\begin{array}{l}\text { S.E. } \\
+/-\end{array}$ & $\begin{array}{c}\text { Radio- } \\
\text { activity } \\
(\mathrm{kBq} / \mathrm{kg})\end{array}$ & $\begin{array}{l}\text { S.E. } \\
+/-\end{array}$ & $\begin{array}{l}\text { weight } \\
\left(\mathrm{g} / \mathrm{m}^{2}\right)\end{array}$ & $\begin{array}{c}\text { Radio- } \\
\text { activity } \\
(\mathrm{kBq} / \mathrm{kg})\end{array}$ & $\begin{array}{l}\text { S.E. } \\
+/-\end{array}$ & $\begin{array}{c}\text { Radio- } \\
\text { activity } \\
(\mathrm{kBq} / \mathrm{kg})\end{array}$ & $\begin{array}{l}\text { S.E. } \\
+/-\end{array}$ \\
\hline $2011 / 7 / 31$ & 7.17 & 62.2 & 3.1 & 76.1 & 3.6 & - & - & - & - & - \\
\hline $2011 / 8 / 19$ & 7.61 & 103.8 & 6.7 & 122.9 & 7.8 & 2.29 & 91.4 & 6.2 & 108.1 & 7.2 \\
\hline $2011 / 9 / 24$ & 27.01 & 75.4 & 2.2 & 67.0 & 1.9 & 7.70 & 91.2 & 3.6 & 108.0 & 3.7 \\
\hline $2011 / 10 / 21$ & 21.72 & 23.0 & 1.4 & 22.9 & 1.2 & 4.23 & 73.6 & 3.9 & 89.3 & 4.0 \\
\hline $2011 / 11 / 5$ & 45.71 & 17.0 & 1.1 & 16.3 & 0.9 & 39.89 & 109.9 & 3.0 & 96.2 & 2.3 \\
\hline $2011 / 11 / 12$ & 44.98 & 21.2 & 1.3 & 18.4 & 1.0 & 9.99 & 74.9 & 2.9 & 91.0 & 3.1 \\
\hline $2011 / 11 / 19$ & 52.49 & 6.4 & 0.8 & 7.7 & 0.8 & 13.33 & 81.1 & 2.9 & 93.5 & 3.0 \\
\hline $2011 / 12 / 5$ & 56.25 & 15.0 & 1.5 & 13.0 & 1.2 & 6.75 & 77.7 & 3.6 & 100.9 & 4.1 \\
\hline $2011 / 12 / 28$ & 29.49 & 28.4 & 1.9 & 30.5 & 2.1 & 0.57 & 0.0 & 0.0 & 69.4 & 8.4 \\
\hline $2012 / 1 / 24$ & 4.04 & 47.1 & 3.7 & 68.1 & 4.6 & 0.49 & 21.7 & 5.5 & 36.5 & 5.0 \\
\hline $2012 / 3 / 9$ & 2.35 & 35.2 & 2.8 & 49.0 & 3.3 & 0.25 & 0.0 & 0.0 & 19.2 & 4.5 \\
\hline $2012 / 5 / 25$ & 48.35 & 36.5 & 1.6 & 41.6 & 1.7 & 38.11 & 35.5 & 1.6 & 45.7 & 1.9 \\
\hline
\end{tabular}

表-1.つづき

Continue.

\begin{tabular}{|c|c|c|c|c|c|}
\hline \multirow[b]{4}{*}{ Sampling date } & \multicolumn{5}{|c|}{ Hardwood-pine mixed forest } \\
\hline & & \multirow{2}{*}{\multicolumn{2}{|c|}{ (Total) }} & & \\
\hline & \multirow{2}{*}{$\begin{array}{c}\text { Dry weight } \\
\left(\mathrm{g} / \mathrm{m}^{2}\right)\end{array}$} & & & \multicolumn{2}{|c|}{${ }^{137} \mathrm{Cs}$} \\
\hline & & $\begin{array}{c}\text { Radio- } \\
\text { Activity } \\
(\mathrm{kBq} / \mathrm{kg})\end{array}$ & $\begin{array}{l}\text { S.E. } \\
+/-\end{array}$ & $\begin{array}{c}\text { Radio- } \\
\text { Activity } \\
(\mathrm{kBq} / \mathrm{kg})\end{array}$ & $\begin{array}{l}\text { S.E. } \\
+/-\end{array}$ \\
\hline $2011 / 7 / 31$ & 7.17 & 62.2 & 2.2 & 76.1 & 2.6 \\
\hline 2011/8/19 & 9.90 & 101.0 & 6.5 & 119.5 & 7.5 \\
\hline $2011 / 9 / 24$ & 34.71 & 78.9 & 3.0 & 76.1 & 3.0 \\
\hline $2011 / 10 / 21$ & 25.95 & 31.2 & 2.9 & 33.7 & 3.0 \\
\hline $2011 / 11 / 5$ & 85.60 & 60.3 & 2.3 & 53.5 & 1.8 \\
\hline 2011/11/12 & 54.97 & 30.9 & 2.2 & 31.6 & 2.3 \\
\hline 2011/11/19 & 65.82 & 21.5 & 2.2 & 25.1 & 2.2 \\
\hline $2011 / 12 / 5$ & 63.00 & 21.8 & 2.7 & 22.5 & 3.0 \\
\hline 2011/12/28 & 30.06 & 27.9 & 1.4 & 31.2 & 6.1 \\
\hline 2012/1/24 & 4.53 & 44.3 & 4.7 & 64.6 & 4.8 \\
\hline $2012 / 3 / 9$ & 2.60 & 31.8 & 2.0 & 46.1 & 4.0 \\
\hline $2012 / 5 / 25$ & 86.46 & 36.1 & 1.6 & 43.4 & 1.8 \\
\hline
\end{tabular}

認められ，特に 11 月 12 日〜 12 月 5 日，3 月 8 日〜 5 月 25 日に大きな值を示した。スギ若齢林ではスギ壮齢林よりや
やリターの降下開始が遅く, 11 月 12 日〜 5 月 25 日にリター 降下が認められた。一方落葉広葉樹一アカマツ混交林では, 広葉樹のリター降下量は 8 月 19 日〜 12 月 5 日に顕著に多 くなり，12月 5 日以降は減少した。アカマッでは 10 月 21 日〜12月 5 日のリター降下量が最も大きい值を示したが, 各採取期間を通してリター降下量は広葉樹と比べて小さ かった。

\section{2. 放射性セシウムの降下量}

リターとともに降下した放射性セシウム量の推移を確認 するため, 観測開始当初からの累積值を算出した。結果 を図-4（a)〜 (e) に示す。放射性セシウム降下量累積值は ${ }^{134} \mathrm{Cs}$ と ${ }^{137} \mathrm{Cs}$ とではほぼ類似した傾向を示した。総じて放 射性セシウム降下量累積值は, 針葉樹林の方が落葉広葉樹一 アカマツ混交林よりも大きな值を示すことが確認された。 また, 累積值の上昇率も, 落葉広葉樹一アカマツ混交林で は減少傾向が認められるのに対し, 針葉樹林では依然とし て顕著な上昇傾向を示していることが確認された。

期間を通じての針葉樹林の放射性セシウム降下量累積值 

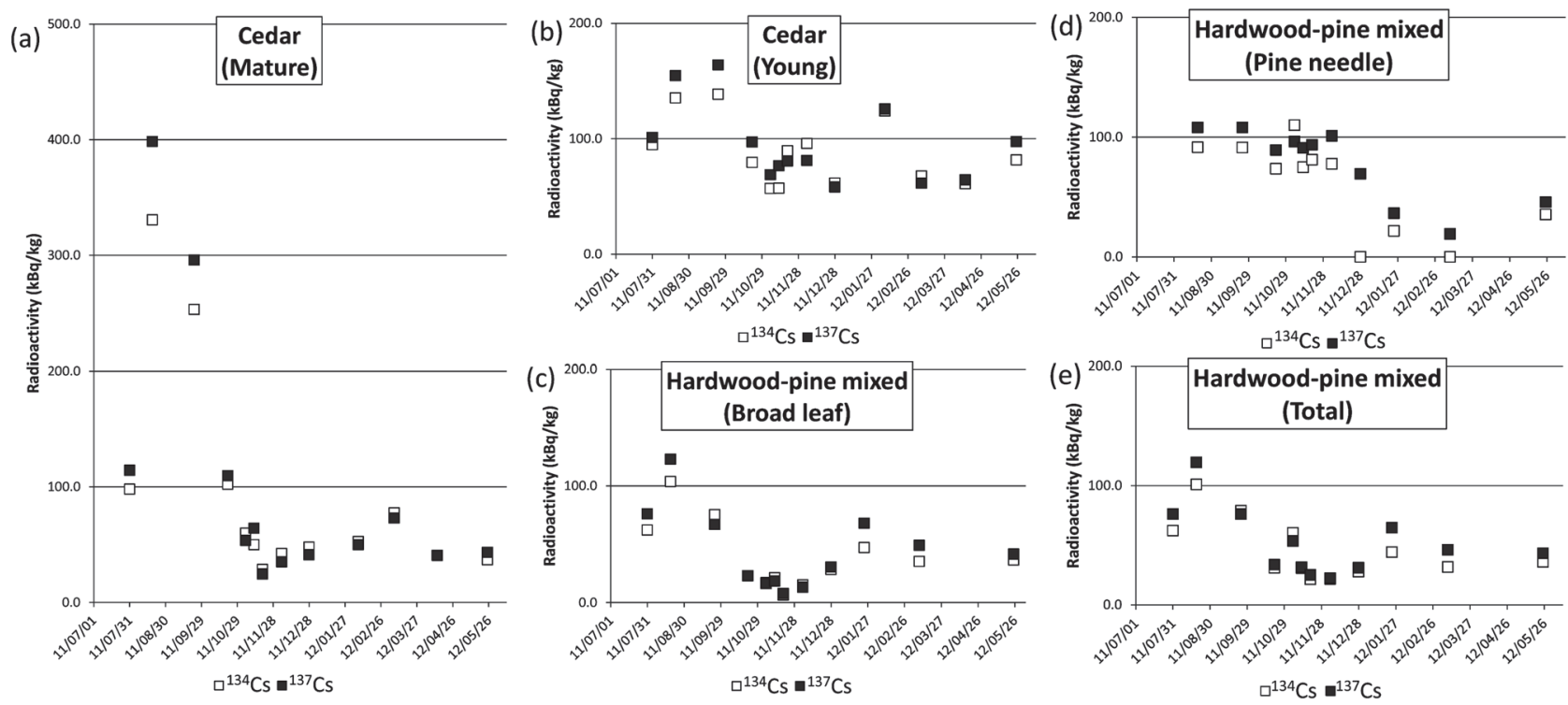

図-3. リターの放射性セシウムの放射能濃度の推移 ( ${ }^{134} \mathrm{Cs}$ および $\left.{ }^{137} \mathrm{Cs} ， 2011 / 7 / 3 \sim 2012 / 5 / 25\right)$

Transition of measured radioactivity about litter samples $\left({ }^{134} \mathrm{Cs}\right.$ and $\left.{ }^{137} \mathrm{Cs}, 2011 / 7 / 3 \sim 2012 / 5 / 25\right)$.

(a) Mature cedar forest, (b) Young cedar forest, (c) Hardwood-Japanese red pine mixed forest (broad leaf), (d) Hardwood-Japanese red pine mixed forest (pine), (e) Hardwood-Japanese red pine mixed forest (total).
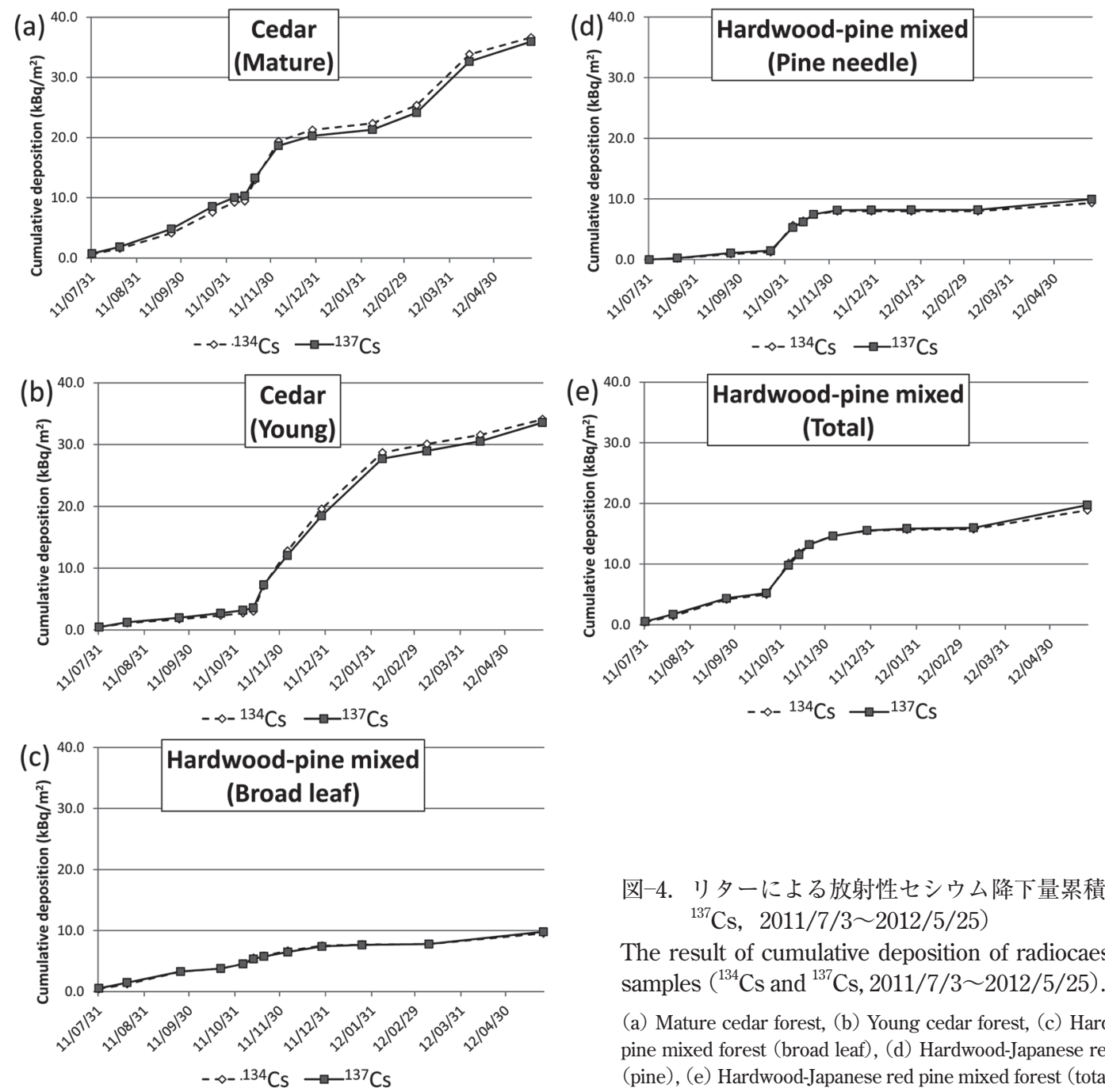

図-4. リターによる放射性セシウム降下量累積值 $\left({ }^{134} \mathrm{Cs}\right.$ および ${ }^{137} \mathrm{Cs}, 2011 / 7 / 3 \sim 2012 / 5 / 25$ )

The result of cumulative deposition of radiocaesium about litter samples $\left({ }^{134} \mathrm{Cs}\right.$ and $\left.{ }^{137} \mathrm{Cs}, 2011 / 7 / 3 \sim 2012 / 5 / 25\right)$.

(a) Mature cedar forest, (b) Young cedar forest, (c) Hardwood-Japanese red pine mixed forest (broad leaf), (d) Hardwood-Japanese red pine mixed forest (pine), (e) Hardwood-Japanese red pine mixed forest (total). 
はスギ壮齢林が ${ }^{134} \mathrm{Cs}$ で $36.6 \mathrm{kBq} / \mathrm{m}^{2},{ }^{137} \mathrm{Cs}$ で $35.9 \mathrm{kBq} /$ $\mathrm{m}^{2}$ (図-4 (a)), スギ若齢林が ${ }^{134} \mathrm{Cs}$ で $34.1 \mathrm{kBq} / \mathrm{m}^{2},{ }^{137} \mathrm{Cs}$ で $33.6 \mathrm{kBq} / \mathrm{m}^{2}$ であり（図-4(b))，同程度の值を示した。 このうちスギ壮齢林では 11 月 12 日〜 12 月 5 日抢よび 3 月 8 日〜 4 月 13 日の期間降下量が大きく, スギ若齢林で は 11 月 12 日〜2月 7 日の期間降下量が大きい值を示した。

一方，落葉広葉樹一アカマツ混交林の放射性セシウム

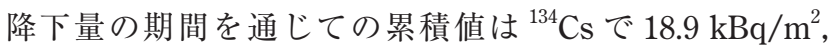
${ }^{137} \mathrm{Cs}$ で $19.7 \mathrm{kBq} / \mathrm{m}^{2}$ であり（図-4（e)），いずれも針葉樹 林での值が落葉広葉樹一アカマツ混交林での值を上回って いた。落葉広葉樹一アカマツ混交林の放射性セシウム降下 量累積值の内訳は, 広葉樹が ${ }^{134} \mathrm{Cs}$ で $9.6 \mathrm{kBq} / \mathrm{m}^{2},{ }^{137} \mathrm{Cs}$ で 9.8 $\mathrm{kBq} / \mathrm{m}^{2}$ であるのに対し(図-4 (c)), アカマッが ${ }^{134} \mathrm{Cs}$ で 9.3 $\mathrm{kBq} / \mathrm{m}^{2},{ }^{137} \mathrm{Cs}$ で $9.9 \mathrm{kBq} / \mathrm{m}^{2}$ であり（図-4(d)), 広葉樹 とアカマツとの間では顕著な差異は認められなかった。広 葉樹は，観測期間を通じて比較的なだらかに放射性セシウ ム降下量累積值の上昇傾向が認められたのに対し，アカマ ツは，10月 21 日〜 12 月 5 日の期間降下量が大きく，他の 期間は少ない期間降下量で推移しており，広葉樹とアカマ ツとで放射性セシウム降下量の累積傾向が異なることが明 らかとなった。

\section{3. リターの部位別の放射能濃度}

将来，森林環境において循環する放射性セシウムの数值 モデルを構築するうえで，林相の違いだけではなく，根か らの吸い上げや樹体内における放射性物質の移行過程を反 映した樹木の樹皮，葉，芽，枝などの異なる部位における 放射能濃度を把握しておくことにより，部位別の放射能濃 度に基づいたより精緻なシミュレーションモデルを構築し ていくことができる（Goor and Avila 2003）。

2012 年 4 月 13 日〜 5 月 25 日に捕捉されたリターを対 象に，部位別の放射能濃度を測定した結果を表-2に示す。 針葉樹林では，スギ壮齢林およびスギ若齢林ともに皮の 試料で放射能濃度が最も高く, ${ }^{134} \mathrm{Cs}$ で $124.1 \sim 223.0 \mathrm{kBq} /$ $\mathrm{kg},{ }^{137} \mathrm{Cs}$ で $185.2 \sim 264.1 \mathrm{kBq} / \mathrm{kg}$ を示した。皮以外の試 料では，スギ若齢林の葉の試料が ${ }^{134} \mathrm{Cs}$ で $130.3 \mathrm{kBq} / \mathrm{kg}$, ${ }^{137} \mathrm{Cs}$ で $152.3 \mathrm{kBq} / \mathrm{kg}$ と高い值を示した。それ以外の試料 では ${ }^{134} \mathrm{Cs}$ で $12.2 \sim 54.9 \mathrm{kBq} / \mathrm{kg},{ }^{137} \mathrm{Cs}$ で $18.8 \sim 67.1 \mathrm{kBq} /$ $\mathrm{kg}$ を示した。針葉樹林に対し，落葉広葉樹一アカマツ混交 林では部位による放射能濃度の差は小さかった。 ${ }^{134} \mathrm{Cs}$ で $20.0 \sim 50.0 \mathrm{kBq} / \mathrm{kg},{ }^{137} \mathrm{Cs}$ で $27.9 \sim 61.3 \mathrm{kBq} / \mathrm{kg}$ であった。

また，各部位の放射能濃度の平均值では，スギ若齢林が 他の林分と比較して最も高い值を示し, ${ }^{134} \mathrm{Cs}$ で $81.6 \mathrm{kBq} /$ $\mathrm{kg},{ }^{137} \mathrm{Cs}$ で $97.6 \mathrm{kBq} / \mathrm{kg}$ であった。スギ壮龄林と落葉広葉 樹ーアカマツ混交林では同程度の值を示しており，スギ壮 齢林では ${ }^{134} \mathrm{Cs}$ で $36.9 \mathrm{kBq} / \mathrm{kg},{ }^{137} \mathrm{Cs}$ で $43.3 \mathrm{kBq} / \mathrm{kg}$, 落葉 広葉樹一アカマツ混交林では ${ }^{134} \mathrm{Cs}$ で $36.1 \mathrm{kBq} / \mathrm{kg},{ }^{137} \mathrm{Cs}$ で $43.4 \mathrm{kBq} / \mathrm{kg}$ であった。

\section{4. リターの部位別の放射性セシウム降下量}

2012 年 4 月 13 日〜 5 月 25 日に捕捉されたりター試料に ついて部位別に測定した放射能濃度より，部位別の放射性
表-2. 2012 年 5 月 25 日に採取したリターの部位別の放射性セ シウムの放射能濃度 $\left({ }^{134} \mathrm{Cs}\right.$ 拈よび $\left.{ }^{137} \mathrm{Cs}\right)$

The result of measured radioactivity at different parts about litter samples $\left({ }^{134} \mathrm{Cs}\right.$ and $\left.{ }^{137} \mathrm{Cs}, 2012 / 5 / 25\right)$.

\begin{tabular}{|c|c|c|c|c|c|}
\hline \multirow[b]{2}{*}{$\begin{array}{c}\text { Cedar forest } \\
\text { (Mature) }\end{array}$} & \multirow[b]{2}{*}{$\begin{array}{l}\text { Dry-wt } \\
\left(\mathrm{g} / \mathrm{m}^{2}\right)\end{array}$} & \multicolumn{2}{|c|}{${ }^{134} \mathrm{Cs}$} & \multicolumn{2}{|c|}{${ }^{137} \mathrm{Cs}$} \\
\hline & & $\begin{array}{c}\text { Radio- } \\
\text { Activity } \\
(\mathrm{kBq} / \mathrm{kg})\end{array}$ & $\begin{array}{l}\text { S.E. } \\
+/-\end{array}$ & $\begin{array}{c}\text { Radio- } \\
\text { Activity } \\
(\mathrm{kBq} / \mathrm{kg})\end{array}$ & $\begin{array}{l}\text { S.E. } \\
+/-\end{array}$ \\
\hline Leaves & 31.70 & 54.9 & 2.4 & 62.5 & 2.6 \\
\hline Branches & 3.38 & 12.2 & 2.7 & 18.8 & 3.0 \\
\hline Bark & 0.49 & 124.1 & 11.0 & 185.2 & 12.9 \\
\hline Seeds & 40.55 & 23.8 & 1.4 & 28.8 & 1.5 \\
\hline \multirow[t]{2}{*}{ Total } & 76.11 & 36.9 & 5.8 & 43.3 & 6.8 \\
\hline & & \multicolumn{2}{|c|}{${ }^{134} \mathrm{Cs}$} & \multicolumn{2}{|c|}{${ }^{137} \mathrm{Cs}$} \\
\hline $\begin{array}{l}\text { Cedar forest } \\
\text { (Young) }\end{array}$ & $\begin{array}{l}\text { Dry-wt } \\
\left(\mathrm{g} / \mathrm{m}^{2}\right)\end{array}$ & $\begin{array}{c}\text { Radio- } \\
\text { Activity } \\
(\mathrm{kBq} / \mathrm{kg})\end{array}$ & $\begin{array}{l}\text { S.E. } \\
+/-\end{array}$ & $\begin{array}{c}\text { Radio- } \\
\text { Activity } \\
(\mathrm{kBq} / \mathrm{kg})\end{array}$ & $\begin{array}{l}\text { S.E. } \\
+/-\end{array}$ \\
\hline Leaves & 16.63 & 130.3 & 3.9 & 152.3 & 4.2 \\
\hline Branches & 1.78 & 46.8 & 2.8 & 67.1 & 3.5 \\
\hline Bark & 0.24 & 223.0 & 29.6 & 264.1 & 32.5 \\
\hline Seeds & 12.47 & 18.9 & 1.3 & 25.8 & 1.6 \\
\hline \multirow[t]{2}{*}{ Total } & 31.12 & 81.6 & 15.0 & 97.6 & 16.5 \\
\hline & & \multicolumn{2}{|c|}{${ }^{134} \mathrm{Cs}$} & \multicolumn{2}{|c|}{${ }^{137} \mathrm{Cs}$} \\
\hline $\begin{array}{l}\text { Hardwood-pine } \\
\text { mixed forest }\end{array}$ & $\begin{array}{l}\text { Dry-wt } \\
\left(\mathrm{g} / \mathrm{m}^{2}\right)\end{array}$ & $\begin{array}{c}\text { Radio- } \\
\text { Activity } \\
(\mathrm{kBq} / \mathrm{kg})\end{array}$ & $\begin{array}{l}\text { S.E. } \\
+/-\end{array}$ & $\begin{array}{c}\text { Radio- } \\
\text { Activity } \\
(\mathrm{kBq} / \mathrm{kg})\end{array}$ & $\begin{array}{l}\text { S.E. } \\
+/-\end{array}$ \\
\hline Leaves (hardwood) & 18.88 & 30.3 & 1.6 & 37.3 & 1.7 \\
\hline Branches (hardwood) & 29.46 & 40.5 & 1.6 & 44.3 & 1.6 \\
\hline Bark (pine) & 8.47 & 29.4 & 1.8 & 41.3 & 2.1 \\
\hline Seeds (pine) & 12.67 & 20.0 & 1.0 & 27.9 & 1.5 \\
\hline Needles (pine) & 16.97 & 50.0 & 1.9 & 61.3 & 2.1 \\
\hline Hardwood total & 48.35 & 36.5 & 1.6 & 41.6 & 1.7 \\
\hline Pine total & 38.11 & 35.5 & 1.6 & 45.7 & 1.9 \\
\hline Total & 86.46 & 36.1 & 1.6 & 43.4 & 1.8 \\
\hline
\end{tabular}

セシウム降下量を算出した。解析結果を図-5（a)〜 (c) に 示す。針葉樹林では，スギ壮齢林，スギ若齢林ともに葉の 試料で最も放射性セシウム降下量が大きくなる傾向が認め

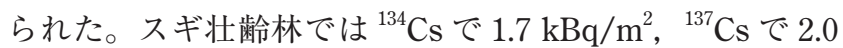

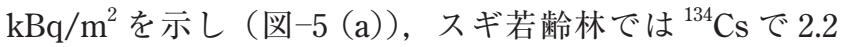
$\mathrm{kBq} / \mathrm{m}^{2},{ }^{137} \mathrm{Cs}$ で $2.5 \mathrm{kBq} / \mathrm{m}^{2}$ を示した（図-5(b))。次い で，スギ壮齢林の種子の試料で放射性セシウム降下量が 大きく, ${ }^{134} \mathrm{Cs}$ で $1.0 \mathrm{kBq} / \mathrm{m}^{2},{ }^{137} \mathrm{Cs}$ で $1.2 \mathrm{kBq} / \mathrm{m}^{2}$ であっ た（図-5 (a))。その他の部位の試料では, ${ }^{134} \mathrm{Cs}$ で $0.0 \sim 0.2$ $\mathrm{kBq} / \mathrm{m}^{2},{ }^{137} \mathrm{Cs}$ で $0.1 \sim 0.3 \mathrm{kBq} / \mathrm{m}^{2}$ であった。

落葉広葉樹一アカマツ混交林では, 部位別の放射性セシ ウム降下量の差は，針葉樹林と比較するとより小さい傾 向を示した。最も放射性セシウム降下量が大きかったの は広葉樹の枝の試料であり, ${ }^{134} \mathrm{Cs}$ で $1.2 \mathrm{kBq} / \mathrm{m}^{2},{ }^{137} \mathrm{Cs}$ で $1.3 \mathrm{kBq} / \mathrm{m}^{2}$ を示した（図-5 (c))。広葉樹の葉の試料では ${ }^{134} \mathrm{Cs}$ で $0.6 \mathrm{kBq} / \mathrm{m}^{2},{ }^{137} \mathrm{Cs}$ で $0.7 \mathrm{kBq} / \mathrm{m}^{2}$ と, 枝の試料の 半分程度の放射性セシウム降下量を示した。アカマッでは 枝の試料の放射性セシウム降下量が最も大きく, ${ }^{134} \mathrm{Cs}$ で $0.8 \mathrm{kBq} / \mathrm{m}^{2},{ }^{137} \mathrm{Cs}$ で $1.0 \mathrm{kBq} / \mathrm{m}^{2}$ であった。一方, アカマ ツの皮と種子の試料では放射性セシウム降下量が小さく, ${ }^{134} \mathrm{Cs}$ で $0.2 \sim 0.3 \mathrm{kBq} / \mathrm{m}^{2},{ }^{137} \mathrm{Cs}$ で $0.3 \sim 0.4 \mathrm{kBq} / \mathrm{m}^{2}$ であっ た。広葉樹とアカマッそれぞれの放射性セシウム降下量の 

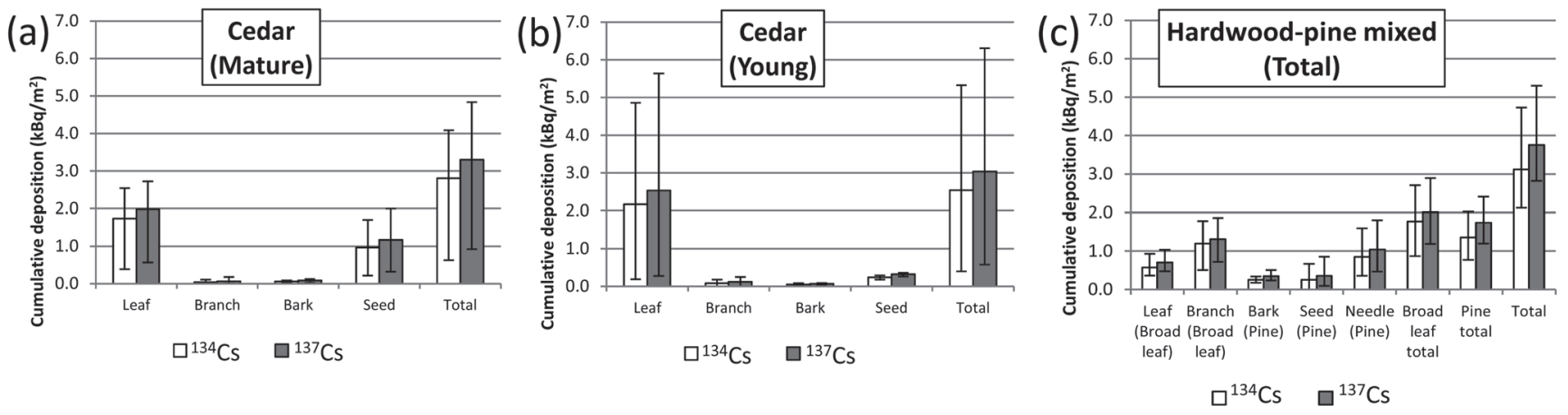

図-5. 2012 年 5 月 25 日に採取したリターによる部位別の放射性セシウム降下量 $\left({ }^{134} \mathrm{Cs}\right.$ および $\left.{ }^{137} \mathrm{Cs}\right)$

The result of cumulative deposition of radiocaesium at different parts about litter samples $\left({ }^{134} \mathrm{Cs}\right.$ and $\left.{ }^{137} \mathrm{Cs}, 2012 / 5 / 25\right)$.

(a) Mature cedar forest, (b) Young cedar forest, (c) Hardwood-Japanese red pine mixed forest. The boxes show the mean values, and the error bars show the maximum and minimum values.

合計值を比較すると, 広葉樹は ${ }^{134} \mathrm{Cs}$ で $1.8 \mathrm{kBq} / \mathrm{m}^{2},{ }^{137} \mathrm{Cs}$ で $2.0 \mathrm{kBq} / \mathrm{m}^{2}$ であったのに対し，アカマッは ${ }^{134} \mathrm{Cs}$ で 1.4 $\mathrm{kBq} / \mathrm{m}^{2},{ }^{137} \mathrm{Cs}$ で $1.7 \mathrm{kBq} / \mathrm{m}^{2}$ であった。

各林分での放射性セシウム降下量の合計值を比較する と, 落葉広葉樹一アカマツ混交林は ${ }^{134} \mathrm{Cs}$ で $3.1 \mathrm{kBq} / \mathrm{m}^{2}$, ${ }^{137} \mathrm{Cs}$ で $3.8 \mathrm{kBq} / \mathrm{m}^{2}$ であるのに対し，スギ壮齢林および若 齢林は ${ }^{134} \mathrm{Cs}$ で $2.5 \sim 2.8 \mathrm{kBq} / \mathrm{m}^{2},{ }^{137} \mathrm{Cs}$ で $3.0 \sim 3.3 \mathrm{kBq} / \mathrm{m} 2$ であった。

\section{IV. 考察}

\section{1. 今後の各林分におけるリターの放射能濃度および放 射性セシウム降下量の推移}

樹種，樹齢が異なる三つの林分で，樹冠から林床へと降 下するリターの放射性セシウムの放射能濃度と降下量累積 值の推移に異なる傾向が認められた（図 $-3,4$, 表-1)。降 下するリターの放射能濃度については，総じて，針葉樹林 と比較して落葉広葉樹一アカマツ混交林の方でより低い值 を示す傾向が認められた（図-3，表-1）。この理由として， 福島第一原発事故が発生した際に広葉樹では落葉してお り，飛散した放射性セシウムの多くが樹冠を通過して林床 へ降下したためと考えられる。このことから，今後，落葉 広葉樹一アカマツ混交林において，降下するリターによる 放射性セシウム降下量累積值は，針葉樹林と比較して大き く上昇することはないと考えられる。一方, 針葉樹林では, 福島第一原発事故の際に拡散した放射性セシウムの沈着し た葉や枝がまだ相当量残存していると考えられるため，今 後も針葉樹林において降下するリターによる放射性セシウ 厶降下量累積值は上昇すると見込まれるが，落葉が進むに つれ，降下量累積值の上昇率は徐々に減少していくものと 考えられる。

今回の調查結果より, 各林分のリターの放射能濃度は 2011 年 10 月頃以降概ね横ばいに推移しており, 放射能濃 度の低下速度が減少してきていることがわかった（図-3,
表-1)。したがって, 同時期以降における各林分での放射 性セシウム降下量累積值の変化傾向は, 樹冠から降下して くるリター降下量に大きく影響されているといえる。2012 年 3 月から 5 月にかけて, 放射性セシウム降下量累積值の 上昇率がスギ壮齢林と落葉広葉樹-アカマツ混交林で増加 しているのも，同様の理由による（図-4, 表-1）。

本研究は 2011 年 3 月に放射性セシウムが森林に降下し てから 4 カ月後 14 カ月後に行ったものであるため, 測 定されたリターの放射能濃度は主に葉や枝に直接付着した 放射性セシウムによるものであると考えられる。これらの リターの放射能濃度および放射性セシウム降下量は, 樹冠 の枝葉に残存する放射性セシウム量の減少や, 放射性セシ ウムの半減期により, 今後, 長期的に減少していくことが 想定される。一方で，林床に降下した放射性セシウムが土 壤へと移行し, 展葉時期に根から吸収されることによって, 再度これらの值が上昇することも考えられることから, 引 き続き時期別および林分別の観測を継続する必要がある。

2. スギ壮齢林におけるリターの放射能濃度急低下の 要因

2011 年 8 月 19 日から 10 月 21 日にかけて, 針葉樹林の スギ壮齢林ではリターの放射性セシウムの放射能濃度が急 に低下するのに比較して，スギ若齢林では緩やかな低下を 示した（図-3（a）（b），表-1）。この傾向と調和的な状況 が, 日本原子力研究開発機構（2013）が同時期に当該針葉 樹林内で高さ別に採取した生葉・枯葉の放射性セシウム $\left({ }^{137} \mathrm{Cs}\right)$ の放射能濃度の測定結果において認められる。生 葉・枯葉の放射能濃度測定結果によると, スギ壮齢林で は 2011 年 7 月 25 日時点では生葉で $46.3 \mathrm{kBq} / \mathrm{kg}$, 枯葉で $119 \mathrm{kBq} / \mathrm{kg}$ であった放射能濃度が, 11 月 18 日には生葉 で $20.5 \mathrm{kBq} / \mathrm{kg}$, 枯葉で $31.8 \mathrm{kBq} / \mathrm{kg}$ と低下しており, 特 に枯葉で大きく低下した。これに対し，スギ若齢林での放 射能濃度は生葉 $50.9 \mathrm{kBq} / \mathrm{kg}$, 枯葉 $44.9 \mathrm{kBq} / \mathrm{kg}$ から生葉 $15.8 \mathrm{kBq} / \mathrm{kg}$, 枯葉 $14.2 \mathrm{kBq} / \mathrm{kg}$ と緩やかな低下を示した。 
この傾向は ${ }^{134} \mathrm{Cs}$ でも同様に認められた。すなわち，本研 究で 2011 年 8 月 19 日から 10 月 21 日にかけてスギ壮齢林 内で降下してきたリターによる放射性セシウムの放射能濃 度が急に低下するのは，当該林分に 7 月 25 日時点で樹冠 にとどまっていた放射能濃度の高い枯葉が上記の期間に脱 落したためと考えられる。

対象地である川俣町山木屋の雨量観測所では 2011 年 7 月 31 日〜 月 23 日に $417 \mathrm{~mm}$ もの降雨量が観測されてい る（国土交通省 2011）。これは同観測所での年雨量の $39 \%$ にあたる。特に 8 月 21 日の 4 時〜 5 時に $21 \mathrm{~mm} / \mathrm{h}$ の強い雨, 9 月 21 日の 19 時〜20 時に台風第 15 号に伴う $19 \mathrm{~mm} / \mathrm{h}$ の やや強い雨が確認されている。この降雨の影響で放射性セ シウムの放射能濃度の高い枯葉がスギ壮齢林の樹冠から脱 落してきた可能性も考えられる。

\section{2011 年 7 8 月に認められた放射性セシウムの放射 能濃度の上昇}

各林分において，2011年 7 月 3 日〜 7 月 31 日に降下し たリターと比較して，7月 31 日以降に降下したリターで は放射性セシウムの放射能濃度が上昇している（図 -3 , 表1)。7月 3 日〜31 日における山木屋雨量観測所での降雨量 は $144 \mathrm{~mm}$ であり（国土交通省 2011）， 7 月 5 日の 8～9 時 には $28 \mathrm{~mm} / \mathrm{h}$ の強い雨が確認されていることから，降雨 量については 8 月以降と大きく変わらないといえるもの の, 8 月以降に降下したリターと比較すると放射能濃度は 低い状況であった。この理由として，各林分の樹冠におい て放射性セシウムの付着した葉が 7 月の段階では十分に枯 れていなかったために，リターの降下に伴う放射性セシウ ムの降下量が少なくなったのではないかと考えられる。本 研究において, 各林分では 11〜12月に最も樹冠からのリ ターの降下量が多いことが確認されたが（表-1），放射性 セシウムの付着したリター（特にスギ壮齢林では放射能濃 度の高い枯葉）については 8～9 月の降雨や台風に伴って 降下したものと推察される。この推察については今後更な る検討が必要であるが, 降下してくるリターの部位や生葉・ 枯葉の違いによって放射性セシウムの放射能濃度は変化す ることが考えられることから，降下してくるリターについ てこれらの部位や状態ごとに放射能濃度を経時的に把握し ていくことが今後の課題である。

このように，林内における樹冠から林床へ降下するリ ターの放射能濃度および放射性セシウム降下量の変化傾向 は，森林の樹種や樹齢による落葉特性の違いによって異な ることが明らかとなってきた。各林分における放射能濃度 や放射性セシウム量については，本調查結果で示した林床 へ降下するリターのほかに，樹冠における生葉の鉛直分布 や，林床でのリターの平面分布，林内に降下してくる雨や 樹幹流などによる移行状況と合わせて総合的に機構を解明
していく必要がある。今後, これらの調査結果が, 森林に おける樹冠から林床へ降下するリターによる放射性物質の 移行機構の理解と, 今後の移行量の予測に活用されること が期待される。

本研究は, 総合科学技術会議平成 23 年度科学技術戦略推進費「放射 性物質による環境影響への対策基盤の確立『放射性物質の分布状況等 に関する調查研究』」および日本原子力研究開発機構 平成 23 年度放射 能測定調査委託事業「福島第一原子力発電所事故に伴う放射性物質の 第二次分布状況等に関する調査研究」, 文部科学省 平成 24 年度科学研 究費補助金（新学術領域研究）「福島原発事故により放出された放射性 核種の環境動態に関する学際的研究」の一部として行われた。筑波大 学恩田研究室・辻村研究室・土壤環境化学研究室の研究員および学生 の皆さんには, 現地での試料採取に協力をいただき, また室内試料処 理や核種測定, 測定結果の解析に際し助言をいただいた。ここに感謝 の意を表します。

\section{引用文献}

Bonnett PJP, Anderson MA (1993) Radiocaesium dynamics in a coniferous forest canopy: a mid-Eales case study. Sci Total Environ 136: 259-277

Bunzl K, Schimmack W, Kreutzer K, Schierl R (1989) Interception and retention of chernobyl-derived ${ }^{134} \mathrm{Cs},{ }^{137} \mathrm{Cs}$ and ${ }^{106} \mathrm{Ru}$ in a spruce stand. Sci Total Environ 78: 77-87

Bunzl K, Albers BP, Shimmack W, Rissanen K, Suomela M, Puhakainen M, Rahola T, Steinnes E (1999) Soil to plant uptake of fallout ${ }^{137} \mathrm{Cs}$ by plants from boreal areas polluted by industrial emissions from smelters. Sci Total Environ 234: 213-221

Goor F, Avila R (2003) Quantitative comparison of models of ${ }^{137} \mathrm{Cs}$ cycling in forest ecosystems. Environ Model Software 18: 273-279

Hashimoto S, Ugawa S, Nanko K, Shichi K (2012) The total amounts of radioactively contaminated materials in forests in Fukushima, Japan. Sci Rep 2: 416: 1-5

Kato H, Onda Y, Teramage M (2012) Depth distribution of ${ }^{137} \mathrm{Cs},{ }^{134} \mathrm{Cs}$, and ${ }^{131} \mathrm{I}$ in soil profile after Fukushima Dai-ichi Nuclear Power Plant Accident. J Environ Radioactiv 111: 59-64

国土交通省 (2011) 水文水質データベース 水文水質観測所情報. http:// www1.river.go.jp/cgi-bin/SiteInfo.exe?ID=102011282218120（2013 年 8 月 14 日アクセス)

文部科学省 (2011) 文部科学省による第 3 次航空機モニタリングの測 定結果について. 別紙 2-4 http://radioactivity.nsr.go.jp/ja/conte nts/5000/4858/24/1305819_0708.pdf (2013 年 5 月 18 日アクセス)

文部科学省原子力災害対策支援本部 - 農林水産省農林水産技術会議事 務局（2012）東京電力株式会社福島第一原子力発電所の事故に伴 い放出された放射性物質の分布状況等に関する調查研究結果. 2-135-2-153 http://radioactivity.nsr.go.jp/ja/contents/6000/5522/ 26/5600_201203131000_report2-2.pdf (2013 年 5 月 18 日アクセス)

日本原子力研究開発機構 (2013) 福島第一原子力発電所事故に伴う放 射性物質の第二次分布状況等に関する調查研究. 2-122-2-173 http://www.jaea.go.jp/fukushima/kankyoanzen/mapping_report/ 2nd-japanese/02-05.pdf（2013 年 5 月 18 日アクセス）

Nylèn T, Grip H (1997) The origin and dynamics of ${ }^{137} \mathrm{Cs}$ discharge from a coniferous forest catchment. J Hydrol 192: 338-354

Schimmack W, Förster H, Bunzl K, Kreutzer K (1993) Deposition of radiocesium to the soil by stemflow, throughfall and leaf-fall from beech trees. Radiat Environ Biophy 32:137-150

Tikhomirov FA, Shcheglov AI (1994) Main investigation results on the forest radioecology in the Kyshtym and Chernobyl accident zones. Science Total Environ 157: 45-57 